\title{
Business Establishment Opposition to Southern Ireland's Exit from the United Kingdom
}

\author{
FRANK BARRY
}

After more than a century of political and economic integration, Southern Ireland exited the United Kingdom in 1922. By identifying the leading business firms of the era and the political and religious allegiances of their owners, this paper explores the perspective of the Southern Irish business establishment on the issues involved. While the mass of the population was Catholic and by 1918 favored secession, the business elite is shown to have been predominantly Protestant and strongly supportive of continued integration. Business elite perceptions of the consequences of exiting the United Kingdom are explored, and post-independence economic and business developments assessed in light of the concerns expressed at the time. The paper also charts the post-independence fate of the leading former unionist firms and the erosion and eventual disappearance of the sectarian divisions then prevalent in Irish business life.

Keywords: Nationalism; Economic disintegration; Ireland; Europe 20th

\section{Introduction}

Southern Ireland exited the United Kingdom with the establishment of the Irish Free State in 1922. A majority of the population had expressed

(c) The Author(s), 2021. Published by Cambridge University Press on behalf of the Business History Conference. All rights reserved. This is an Open Access article, distributed under the terms of the Creative Commons Attribution licence (http://creativecommons.org/licenses/by/4.0/), which permits unrestricted re-use, distribution, and reproduction in any medium, provided the original work is properly cited.

doi:10.1017/eso.2021.7

Published online March 22, 2021

FRANK BARRY is Chair of International Business and Economic Development at Trinity College Dublin. Contact information: Trinity Business School, Trinity College Dublin, Dublin 2, Ireland. Email: frank.barry@tcd.ie

I am grateful to the journal's referees for helpful comments and suggestions. 
support for secession when the previously marginal republican party Sinn Féin secured 73 of the 105 Irish seats in the UK general election of 1918. By identifying the leading business firms of the Free State area and the political allegiances of their owners and proprietors, this paper shows that the bulk of the business elite of the time strongly favored retention of the status quo. The paper thus contributes to the study of how business owners and businesses of varying characteristics perceive their interests to be affected by political separation. There has been little research on this issue in the field of business history, though there is an extensive literature on the economics of separation, and the field of international political economy is also germane to the topic. ${ }^{1}$

The situation in Ireland was complicated by the fact that the political fault line between unionism and nationalism overlapped to a large extent with ethno-religious identity as well as with geography and economic structure. The bulk of the island's industry was located in the northern province of Ulster, which had a majority Protestant unionist population. Northern Ireland, which comprised six of the nine counties of Ulster, came into being when the island was partitioned in 1921 and remains to this day part of the United Kingdom. The Free State area, by contrast, was predominantly agricultural in structure and Catholic in religion. Careful analysis has found the pre-partition business establishment on the island of Ireland to have been "overwhelmingly Protestant."2 The composition of the business establishment in the Free State area has been less precisely identified up to this point, though the literature suggests that it too was predominantly Protestant. ${ }^{3}$ There was a less than perfect overlap between Protestantism and unionism, however. While the present paper confirms that the majority of substantial Free State-area business owners were both unionist and Protestant, it finds small minorities of Catholic nationalists, Protestant nationalists, and Catholic unionists among the group.

The gulf between the business establishment and the majority population in the Free State area is the focus of the present paper. There were similar (and frequently much more complex) divisions in many of the other newly established states of the interwar period. ${ }^{4}$ This was not the case in Northern Ireland where, though there was a substantial nationalist minority, the business establishment and the majority population were ad idem in their religious and political allegiances. ${ }^{5}$

1. Hynes, "Separation," provides a survey of the economics literature. On the relevance of international political economy, see Frieden and Martin "Global and Domestic."

2. Campbell, Irish Establishment, 241.which

3. Bielenberg, "Industrial Elite"; Barry, "Protestant Businesses."

4. Aldcroft, European Periphery, 10.

5. Though the island was only partitioned in 1921, the business establishments north and south of the future border can be regarded as largely distinct groups. The 
The paper goes on to explore the divergence in perspectives between the Free State-area business community and the majority population on the implications of Home Rule and secession and examines the policy and performance of the new state over its early decades in light of the concerns expressed by the business community at the time. It tracks what became of the leading unionist firms of the day and charts the legacy and eventual disappearance of the sectarian divisions then prevalent in Irish business life.

Ethno-religious polarization of the type that characterized the state for much of its existence is known to be detrimental to economic growth. ${ }^{6}$ European Economic Community (EEC) membership from 1973 has been credited empirically with unleashing Ireland's growth potential by reducing the country's dependence on the UK economy. ${ }^{7}$ The residue of sectarian divisions in the former Free State area (by now the Republic of Ireland) also finally disappeared around this time. ${ }^{8}$ The growth consequences of this particular aspect of the Irish experience have yet to be explored empirically.

The paper is organized as follows. The next section provides a brief historical overview and is followed by a discussion of the process by which the leading firms of the era are identified. The results of the identification process are then presented. Following sections discuss in turn the major areas of disagreement over exiting the United Kingdom and developments in economic policy and business life postindependence. A final section offers concluding comments.

\section{Historical Overview}

The Irish Free State upon its establishment in 1922 was one of the least industrialized countries in western Europe. ${ }^{9}$ Northern Ireland had a

areas specialized in different sectors, and trade-when not primarily local-was largely east-west (across the Irish Sea) rather than north-south. Furthermore, the interests and strategies of northern and southern unionists had grown increasingly divergent since the 1880s: Campbell, Irish Establishment, 180.

6. Montalvo and Reynal-Querol, "Polarization," show in a standard conditional convergence framework that ethno-religious polarization has a negative and significant effect on long-term growth.

7. O’Rourke, "Independent Ireland."

8. The following analysis ascribes this to the economic liberalization of the era and associated developments in the educational sphere. Several papers in the neoclassical tradition have found an association between liberalization and reduced discrimination; Levine, Levkov, and Rubinstein, "Racial Inequality”; Black and Brainerd, "Importing Equality?" Perspectives from segmented labor market theory and stratification economics are also likely to be of relevance; see, e.g., Chen et al., "Globalization.”

9. Of the thirteen European states for which Flora, Kraus, and Pfenning, State, Economy and Society, provide data on the share of industry in the labor force in the 
higher level of income per head and contained the bulk of the island's industry, though it had a population less than half that of the South. ${ }^{10}$ There were differences too in the ethno-religious composition of the populations, with a Protestant majority in the future Northern Ireland and a far larger Catholic majority across the entire island.

The origins and significance of the sectarian divide are succinctly summarized in an official publication of the Northern Irish government, which notes that the displacement of the native [Catholic] population by English and Scottish settlers from the 1600s

undoubtedly operated to introduce bitter animosities, since the incoming colonists differed both in religion and nationality from the original inhabitants, and, in addition, were regarded with all the odium attaching to supplanters. ${ }^{11}$

Ireland had been integrated politically and economically into the United Kingdom in the early nineteenth century and Protestants, who remained wealthier on average, were for the most part strongly committed to the status quo. The largely Catholic nationalist population, by contrast, had long favored a form of devolved government known as Home Rule but was radicalized by a series of missteps by government in the aftermath of the 1916 Rising. ${ }^{12}$ A showdown was inevitable when the previously obscure Sinn Féin party, whose leadership was openly aligned with the armed paramilitary group that would come to be known as the Irish Republican Army, secured a large majority of the Irish seats in the UK general election of $1918 .{ }^{13}$ Britain, having just emerged victorious from a war that had seen other European empires collapse—and with India and other restless colonies looking on-was not prepared to accede to the demand for an independent Irish Republic. A period of guerrilla warfare ensued, the island was partitioned and,

1920s, the Irish Free State is ranked second lowest after Finland (the only other recently established state among the thirteen). The Irish share is less than half that of the unweighted average for the group.

10. Northern Ireland GDP per head (unadjusted for possible differences in the price level) stood at 62 percent of the UK level in 1926 compared to a Free State figure of 56 percent (Kennedy, Giblin and McHugh, Economic Development, table 6.2, p. 124). The Northern Ireland-area linen industry employed 77,000 in 1912 ("Preliminary Reports: Northern Ireland," UK Board of Trade Journal, no. 1, January 26, 1928, 1-10). The entire Free State-area manufacturing sector by contrast employed only sixty-nine thousand at the time (Saorstát Éireann, Census of Industrial Production 1926 and 1929, xxi).

11. Ulster Year Book, x.

12. De Bromhead, Fernihough and Hargaden, "Sinn Féin Election.” British parliamentarians had been divided since Home Rule first appeared on the agenda as to whether it would satisfy or stimulate the appetite for independence.

13. De Bromhead, Fernihough, and Hargaden, "Sinn Féin Election,” 887. 
following the Anglo-Irish Treaty of 1921, the Irish Free State was established with a status equal to that of Canada and the other British Commonwealth dominions.

The experiences of the two parts of Ireland had differed sharply over the course of the nineteenth century. The area that would comprise the future Northern Ireland had industrialized, and the emergence of its export-oriented linen and ship-building industries, supported by a strong engineering sector, had combined with the ethno-religious factor to ensure majority support for the Union. ${ }^{14}$ Southern Ireland's extensive cottage textiles sector, by contrast, had collapsed, and the region had become specialized as a "colonial" supplier of agricultural output to the British market. ${ }^{15}$ Though modern economic historians are skeptical that tariffs could have affected the outcome, nationalist thinking became increasingly protectionist over time. ${ }^{16}$

Big business in the Northern Ireland area was unequivocally unionist. ${ }^{17}$ Southern Irish "big business" has also been presumed to have been antagonistic to Home Rule, though its composition has not been rigorously established until now. ${ }^{18}$ The Dublin Chamber of Commerce had stated in 1892 that though "as a corporate body we have no politics,"

we are essentially a unionist chamber [...] because in defending the union we are defending the commercial interests with which we are identified. ${ }^{19}$

As attitudes became increasingly polarized from the 1890s, however, the desire of the chambers of commerce to avoid fracturing along

14. Kennedy, "Nationalism and Unionism," explores the complex interaction between economics, politics, and religion.

15. On the Industrial Revolution-era transformation of the Irish economy, see O’Malley, “Decline”; Ó Gráda, New Economic History, 308, 348; Kennedy, Colonialism, 41-42. Pollard, Peaceful Conquest, explores the differential regional impacts of the Industrial Revolution across Europe.

16. Ó Gráda, New Economic History, 307; Daly, Irish National Identity, 4-5.

17. There the business elite funded and promoted the threat of armed resistance by the local unionist population to British government proposals that were perceived as threatening to their interests: Ollerenshaw, "Businessmen and Ulster Unionism." For an analysis of the later cozy relationship that prevailed between local business and the devolved Northern Ireland administration, see Brownlow, "Rent-seeking."

18. Southern Irish "big business" is sometimes taken to have consisted of the leading firms in brewing, biscuits, distilling, and jute; Meenan, "Industrial Policy." Employment in the distilling sector and in Guinness, Jacob's, and Goodbody's-the dominant firms in the other three sectors-together accounted for little more than 10 percent of Free State-area factory employment in 1912 (based on data in the present paper and in Saorstát Éireann, Census of Industrial Production 1926 and 1929, xxi).

19. MacMahon, Meeting of Merchants, 140. See also Potter, Limerick's Merchants, 76. 
political and religious lines made them increasingly hesitant to express themselves with such clarity.

\section{Research Process and Data Sources}

Two alternative methods have been employed by researchers seeking to establish the most significant firms of a particular era. One method employs as its metric some measure of stock market capitalization. ${ }^{20}$ Confining the analysis to listed firms would be particularly problematic for the Free State area, however; first, because external firms, which are unlikely to be listed on local stock markets, tend to play a more significant role in smaller less-advanced economies; and second, because family ownership has been, and remains to this day, the dominant pattern among large domestic businesses in what is now the Republic of Ireland. ${ }^{21}$ The other method, which is employed here, focuses on workforce size. ${ }^{22}$ As this would exclude capital-intensive sectors such as distilling, however, this paper also seeks to identify the most significant employers in each individual industry.

There is no single data source that provides the necessary information on firm size. Shaw describes the Red Book of Commerce, a contemporary commercial directory, as "the single most valuable source" for her list of large UK manufacturing employers of $1907 .^{23}$ Ó Gráda employs a list of around 270 Irish manufacturing exporters prepared by the (Irish) Department of Agriculture and Technical Instruction in 1911 to study the pattern of industrial location, presuming that these represent "the bulk of going concerns at the time." ${ }^{24}$ Entries for Southern Ireland in the Red Book are sparse, however, while a substantial number of the large employers unearthed here do not appear on the list employed by Ó Gráda.

The research process began with the construction of a "long list" of candidate firms based on these and other such documents along with a broad range of academic studies and newspaper reports, with component lists compiled for each of the sectoral categories employed in the first (1926) Free State Census of Industrial Production. Stock market listings played a greater role in the case of nonindustrial sectors for which the data are less codified. The railway companies and banks dominated the stock market of the time. As ownership of these

20. See, e.g., Payne, "Large-Scale Company." This is the method largely followed by Campbell, Irish Establishment.

21. O’Gorman and Curran, "Strategic Transformations."

22. Shaw, "Large Manufacturing Employers."

23. Shaw, "Large Manufacturing Employers."

24. Ó Gráda, New Economic History, 312. 
segments was more dispersed than in the case of manufacturing, the focus of attention in these cases is on the political allegiances of the chairs of the boards of directors, who tended to remain in position for periods of up to several decades. Workforce numbers are derived for the most part from contemporary newspaper reports and are then used to isolate the largest firms on the long lists. Those employing five hundred or more in the period to independence are listed in Table $1 .{ }^{25}$ Evidence as to the political affiliations of owners and proprietors is drawn from the diverse sources reported in Appendix 1, while religious affiliation generally comes from the online population censuses of 1901 and 1911.

\section{The Leading Southern Business Firms and the Political Allegiances of Their Proprietors}

That the industrial elite even in Southern Ireland was converging in wealth and influence on the traditional ascendancy class by the early twentieth century was reflected in the leadership of pre-independence southern unionism, of which Lord Midleton and the banker and distiller Andrew Jameson were the principal spokesmen, and in the history of the Guinness brewing family, two of whose members-Lords Ardilaun and Iveagh—had been raised to the peerage. ${ }^{26}$

Guinness was by far the most substantial manufacturer in what would become the Irish Free State. Fewer than two dozen southern manufacturing firms employed a workforce of five hundred or more in 1929. ${ }^{27}$ The Guinness brewery employed around four thousand in the decade to independence. Lords Ardilaun and Iveagh were conservative unionists, and two of Iveagh's sons sat on the Tory benches at Westminster. ${ }^{28}$ Around half of the other breweries, all tiny in comparison, were also unionist owned. ${ }^{29}$ The Quaker biscuit company W. \& R. Jacob was another major employer, with a 1914 workforce of around

25. As Shaw, "Large Manufacturing Employers," notes, there can be no guarantee that the employment method will unearth all of the largest firms. Even more difficult to identify and categorize are individuals such as Catholic nationalist D. E. Williams of Tullamore, whose numerous small enterprises employed an aggregate workforce of substantial size (Freemans Journal, July 11, 1921).

26. Buckland, Irish Unionism, xix.

27. Barry, "Leading Manufacturing Firms." There had been a substantial influx of tariff-jumping foreign firms by 1929 , while a number of the large firms identified here had collapsed or amalgamated by then (Appendix 2).

28. McDowell, Crisis \& Decline, 39.

29. These included Beamish \& Crawford in Cork; the Mountjoy Brewery (Findlater's) and Watkins, Jameson \& Pim in Dublin, the Great Northern Brewery in Dundalk, and the Cairnes breweries at Castlebellingham and Drogheda in County Louth. 
Table 1 Firms in Southern Ireland Employing Five Hundred or More in the Decades to Independence

\begin{tabular}{|c|c|c|c|c|}
\hline Firm & Sector & Religion and political allegiance & Employment in Free State area & Employment: Source \\
\hline Guinness & Brewing & Protestant Unionist & 4,090 (1919) & "Guinness Archive Fact Sheet" \\
\hline W. \& R. Jacob & Biscuits & Protestant Unionist & $3,000(1914)$ & Weekly Irish Times, August 1, 1914 \\
\hline $\begin{array}{l}\text { Condensed Milk Co. of } \\
\text { Ireland }\end{array}$ & Dairy produce & Protestant Unionist & $3,000(1922)$ & Cork Examiner, May 13, 1922 \\
\hline J. \& L. F. Goodbody & Jute textiles & Protestant Unionist & $800(1920)$ & $\begin{array}{l}\text { Riordan, Modern Irish Trade and Industry, } \\
\quad 140 .\end{array}$ \\
\hline Kynoch's & Chemicals & (British) & $2,500(1918)$ & Irish Times, February 16 and 19, 1918 \\
\hline Boland's & Bread & Catholic Nationalist & ca. $500(1900)$ & See references in text. \\
\hline $\begin{array}{l}\text { Johnston, Mooney \& } \\
\text { O’Brien }\end{array}$ & Bread & Protestant Unionist & ca. $500(1900)$ & See references in text. \\
\hline Goulding's & Fertilizer & Protestant Unionist & ca. 800 (1912) & Whitaker's Red Book of Commerce, 1912 \\
\hline Dwyer \& Co. & $\begin{array}{l}\text { Clothing, footwear, } \\
\text { and furnishings }\end{array}$ & Catholic Nationalist & 700 (1918) & Weekly Irish Times, December 7, 1918 \\
\hline Bannatyne & Grain milling & Protestant Unionist & ca. 700 (1920) & See references in text. \\
\hline Blarney Woollen Mills & Woolen textiles & Catholic Nationalist & 600 (1919) & Cork: Its Trade \& Commerce, 171 \\
\hline $\begin{array}{l}\text { Limerick Clothing } \\
\text { Factory }\end{array}$ & Clothing & Protestant Unionist & $600(1914)$ & Evening Herald, September 23, 1914 \\
\hline $\begin{array}{l}\text { Cork Spinning \& } \\
\text { Weaving }\end{array}$ & Linen & Protestant Unionist & 1,000 (1919) & Cork: Its Trade \& Commerce, 173 \\
\hline $\begin{array}{l}\text { Greenmount Spinning \& } \\
\text { Weaving }\end{array}$ & Linen & Protestant Unionist & $550(1922)$ & Irish Times, October 7, 1922 \\
\hline Boyne Weaving & Linen & Protestant, possibly Home Ruler & 900 (1910) & Freemans Journal, May 19, 1910 \\
\hline Hely & $\begin{array}{l}\text { Paper products and } \\
\text { printing }\end{array}$ & Protestant Unionist & 500 (1916) & Irish Times, May 10, 1916 \\
\hline
\end{tabular}


Table 1 (Continued)

\begin{tabular}{|c|c|c|c|c|}
\hline Firm & Sector & Religion and political allegiance & Employment in Free State area & Employment: Source \\
\hline Alexander Thom & $\begin{array}{l}\text { Paper products and } \\
\text { printing }\end{array}$ & Protestant Unionist & $500(1912)$ & Whitaker's Red Book of Commerce, 1912 \\
\hline Ford & Tractors & (American) & $1,429(1920)$ & Grimes, “Ford in Cork," vol. 1, 184. \\
\hline Dublin Dockyard Co. & $\begin{array}{l}\text { Shipbuilding and } \\
\text { repair }\end{array}$ & Protestant Home Ruler & $1,000(1919)$ & $\begin{array}{l}\text { Riordan, Modern Irish Trade and Industry, } \\
\quad 99 .\end{array}$ \\
\hline $\begin{array}{l}\text { Great Southern \& } \\
\text { Western Railway Co. }\end{array}$ & Rail & Protestant Unionist & 8,893 (1913) & Railway Companies: Staff and Wages \\
\hline $\begin{array}{l}\text { Great Northern Railway } \\
\text { Co. }\end{array}$ & Rail & Protestant Unionist & $\begin{array}{l}\text { 5,460 in Ireland (1913) 3,000 in } \\
\text { Free State alone (1925) }\end{array}$ & $\begin{array}{l}\text { Railway Companies: Staff and Wages; } \\
\text { Returns of Railway Companies, } 61\end{array}$ \\
\hline Midland Great Western & Rail & Protestant Unionist & $3,451(1913)$ & Railway Companies: Staff and Wages \\
\hline Dublin \& South Eastern & Rail & $\begin{array}{l}\text { Protestant Unionist, (Catholic } \\
\text { Nationalist from 1921) }\end{array}$ & $1,373(1913)$ & Railway Companies: Staff and Wages \\
\hline Bank of Ireland & Banking & Protestant Unionist & $550(1914)$ & See references in text. \\
\hline National Bank & Banking & Catholic Nationalist & ca. 600 (1919) & See references in text. \\
\hline Pim Bros. & Retail & Protestant Unionist & $600(1894)$ & Irish Times, November 14, 1894 \\
\hline Eason \& Son & $\begin{array}{l}\text { Printing, retail, and } \\
\text { wholesale }\end{array}$ & Protestant Nationalist & ca. 500 (1915) & Cullen, Eason \& Son, 283 \\
\hline $\begin{array}{l}\text { Alliance and Dublin } \\
\text { Consumers Gas Co. }\end{array}$ & Gas & Mixed Unionist and Nationalist & $\geq 750(1917)$ & Freemans Journal, November 7, 1917 \\
\hline $\begin{array}{l}\text { Dublin United Tramway } \\
\text { Company }\end{array}$ & Tramways & Catholic Nationalist & $750-2,000(1913)$ & See references in text. \\
\hline
\end{tabular}


three thousand in Dublin and a further several hundred at its recently established branch plant near Liverpool. The chairman and managing director, George Newson Jacob, was a member of the Dublin Unionist Association and one of a group of businessmen to issue a critique of the economics of Home Rule in $1913 .^{30}$

Irish whiskey had been outcompeted by Scotch by the early twentieth century, and the industry would remain in the doldrums for many decades. Of the four remaining major southern producers, the Dublin Distillers Company - an amalgamation of firms of diverse origins-was ailing and would largely cease production in the 1920s. ${ }^{31}$ Of the other three, only Cork Distilleries was in Catholic nationalist ownership. The chairman of Jameson, Presbyterian unionist Andrew Jameson, also served as governor and director of the Bank of Ireland. ${ }^{32}$ Power's was owned by a Catholic unionist family, the Talbot Powers. Jute was another sector to have emerged amid the deindustrialization of the nineteenth century. ${ }^{33}$ The industry was dominated by the Quaker firm J. and L. F. Goodbody, which employed close to one thousand. Goodbody family members were prominent across a range of professional and business sectors and served on most of the unionist committees of the era.

Other large exporting firms included the Condensed Milk Company of Ireland, chemicals firm Kynoch's, bacon curer Henry Denny \& Sons, and fertilizer producer Goulding's. The Condensed Milk Company was by far the largest of the private creameries to survive the emergence and expansion of the cooperative creameries from the 1890s. By the early 1920s, it was estimated to process one-thirtieth of the entire dairy produce of Southern Ireland. ${ }^{34}$ The company prospered during World War I but collapsed with the sharp decline in agricultural product prices that followed. With a workforce of several thousand across Munster, it was controlled from its Limerick City base by the "strongly unionist" businessman Sir Thomas Henry Cleeve. ${ }^{35}$ The Cleeves were members of the Church of Ireland, the major Protestant denomination in the South.

The leading foreign-owned manufacturing company before Ford's commencement of operations in Cork city in 1919 was Birmingham firm Kynoch's. Kynoch's was owned by Arthur Chamberlain, brother of the prominent British Liberal Unionist MP who had split with

30. Irish Independent, November 11, 1913.

31. Townsend, Lost Distilleries.

32. Buckland, Irish Unionism, xix; Pauric J. Dempsey, "Jameson, Andrew," Dictionary of Irish Biography.

33. Meenan, "Industrial Policy."

34. Cork Examiner, January 9, 1924.

35. Shaun Boylan, "Cleeve, Sir Thomas Henry," Dictionary of Irish Biography. 
Gladstone upon the latter's conversion to Home Rule. Around three thousand jobs were lost when its cordite, explosives, and chemicals plant at Arklow closed in 1918. Denny \& Sons was one of the most significant firms in the UK bacon trade and a major supplier to the wartime British military. ${ }^{36}$ It employed around five hundred in peacetime, and perhaps substantially more in 1914 to $1918 .{ }^{37}$ The chairman, Charles Edmond Denny, served on the General Council of the Irish Unionist Alliance. Goulding's, by far the largest fertilizer producer, employed some 1,200 in its nine Irish plants in 1912, six of which were in the area that would become the Irish Free State. ${ }^{38}$ Sir William Goulding was a leading southern unionist, and his brother, Lord Wargrave, sat as a Unionist member of the House of Commons until raised to a peerage in $1922 .^{39}$

Other than the long-established Blarney Woollen Mills of Martin Mahony \& Brothers, all of the substantial export-oriented textile and clothing companies were also under Protestant unionist control. Limerick Clothing, established by Scottish expatriate Peter Tait, had developed an international reputation as a producer of military uniforms in the 1800s. Tait went bankrupt when a consignment of Alabama cotton bartered for Confederate uniforms was seized by Union forces during the American civil war and the company was taken over in the 1890s by a group of Limerick businessmen, the most prominent of whom was the unionist milling magnate J. F. G. Bannatyne. ${ }^{40}$ Though much diminished in size compared to its earlier incarnation, it continued to employ more than six hundred during World War I.

There were two major hosiery firms in Balbriggan in north Dublin: Smyth \& Company, which was owned by local Church of Ireland unionist family the Whytes, and the Sea Banks hosiery facility of English firm Deeds, Templar \& Company, which was destroyed when Balbriggan was ransacked by British forces in 1920. ${ }^{41}$ Each employed around four hundred, though most were outworkers. ${ }^{42}$ The largest southern linen firm, Cork Spinning \& Weaving, was owned by the Presbyterian unionist family the Ogilvies and employed around one thousand. Greenmount Spinning \& Weaving of Dublin and Boyne Weaving of Drogheda were slightly smaller. Greenmount was owned

36. Henry Denny \& Sons, Brief History, 3; Irish Times, April 18, 1917.

37. There were 350 employed at two of its several factories in Waterford and Limerick in 1895 (Cork Examiner, October 12, 1895). Employment at its Cork plant stood at “well over 100" around this time (Weekly Irish Times, July 10, 1909).

38. Whitaker's Red Book of Commerce.

39. Weekly Irish Times, July 18, 1925.

40. Slater, Stitch in Time, 48.

41. Irish Times, February 1, 1921.

42. Barry, "Leading Manufacturing Firms." 
by the Pims, a Quaker unionist family, and Boyne Weaving by an Ulster Presbyterian who may have been among a group of Protestant Home Rulers. ${ }^{43}$ Smaller firms in the sector, some under Catholic ownership, were fearful of the disruption of the linen supply chain that partition would entail and viewed the establishment of the Free State with disquiet.

Domestically oriented sectors hosted a number of significant Catholic nationalist firms, including the wholesale drapery, general furnishings, and footwear operations of the Cork firm Dwyer \& Company. Even in these sectors, however, most of the large firms were under unionist ownership. Within manufacturing, breadmaking, woolen and worsted textiles, and leather stood out as the only segments in which the largest firms were predominantly Catholic and nationalist. ${ }^{44}$

Flour milling was dominated by the Limerick-based Bannatyne group, in which the Goodbody family built up a controlling stake from the 1890s. Employment in Bannatyne and its subsidiaries is likely to have exceeded seven hundred in this period. ${ }^{45}$ Other unionist flour millers included the Church of Ireland families the Odlums and the Pollexfens (maternal family of the poet W. B. Yeats). Two of the four industrial-scale bread producers-Johnston, Mooney \& O'Brien and F. H. Thompson-were Protestant and unionist; the other twoBoland's and Kennedy's-were under Catholic nationalist ownership. Johnston, Mooney \& O'Brien and Boland's were the largest and of broadly similar size. ${ }^{46}$ John Mooney, principal of the former, was a leading local unionist politician, the largest shareholder in the company was Sir Robert Gardner (on whom more later), and the long-term chairman was a member of the Pim family. ${ }^{47}$ Most of the sugar

43. The Ulster Presbyterian proprietor of Boyne Weaving was inspector of industries for the Congested Districts Board. He inherited the factory from an uncle of the same background who had been a Gladstonian Liberal and supporter of Home Rule (Irish Times, May 11, 1926; June 18, 1909). The chairman of the company was a Belfast Unitarian. (Many Protestant nationalists tended to be members of smaller religious groupings.)

44. On the leather industry, see Riordan, Irish Trade and Industry, 178; Bielenberg, Cork, 82. There is no single thread connecting these sectors. Daly deems it of significance that both William Martin Murphy, the leading Catholic nationalist industrialist of the era, and William Dargan, an earlier major Catholic industrialist, operated in home market-oriented sectors; Daly, Social and Economic History, 84. While bread was home market oriented, woolens and worsted had a 50 percent export-output ratio in 1926. Data for the leather sector, which was very small, are not available.

45. Barry, "Leading Manufacturing Firms"; Irish Times, January 23, 1923.

46. Daly reports an employment level of eight hundred for Boland's in 1888; Daly, Deposed Capital, 32. By 1925 this had declined to 420 (Irish Times, May 22, 1925). Johnston, Mooney \& O’Brien appears to have employed around six hundred in 1904 (Freemans Journal, May 16, 1904).

47. Irish Times, February 18, 1919. 
confectionery and jam producers were Protestant owned, as was the case also in sectors cognate to brewing, where the influence of Guinness loomed large. One of the most significant maltsters was John H. Bennett \& Company, with which Guinness worked closely in developing new strains of barley. The Bennetts, like the Guinnesses, were Church of Ireland unionists. ${ }^{48}$ E. \& J. Burke had been established in business by their Guinness cousins as the brewery's export bottlers, and by 1892 their Liverpool house, under the management of Sir John Nutting, was said to be the most important bottling establishment in the world. ${ }^{49}$ Nutting, who had shortly afterward become sole proprietor, was a prominent unionist, as was Sir Henry Cochrane, proprietor of the largest mineral water producer, Cantrell \& Cochrane. Other than the industrial bakers, these firms all employed well under five hundred, as did the leading local tobacco manufacturers, Goodbody's and the Catholic nationalist firm Carroll's of Dundalk. While footwear was largely imported and the sector hosted no substantial firms, paper products and printing enjoyed a degree of natural protection, and the two most substantial firms in these segments, Hely's and Alexander Thom \& Company, each employed around five hundred. Thom's was chaired by a member of the Pim family, and successive managing directors took an active part in unionist politics. There is evidence too of the Hely family's support of conservative unionist causes. ${ }^{50}$ Printer and bookseller Eason's also employed five hundred or more in the Free State Area, one hundred or so in their print works, and the remainder in the wholesale and retail side of the business. Though Presbyterian and private in their politics, the Easons were nationalist in their sympathies. $^{51}$

The largest employer in metals and engineering in 1920 was the recently established Henry Ford \& Son, which would shortly afterward be integrated into the Ford Motor Company. Ford's decision to open an Irish operation had been made when Home Rule was anticipated. The establishment of the Free State was damaging to the company as the McKenna tariffs were levied on its trade with Britain and Northern Ireland. ${ }^{52}$ The other large employer in the sector was the Dublin Dockyard Company, under the control of Scottish-born Presbyterian John Smellie. It employed around one thousand in 1919, shortly before its closure. The largest Catholic nationalist firm in the sector was Phillip Pierce \& Company of Wexford, whose agricultural machinery and cycle

48. Gibney and Quinn, "Bennetts."

49. Strattens' South of Ireland, 36.

50. Freemans Journal, November 26, 1910; Weekly Irish Times, December $3,1910$.

51. Cullen, Eason \& Son, 138-9.

52. Grimes, Henry Ford, vol. 2, 1-5. 
factory, the Mill Road Ironworks, employed some three to four hundred in $1911 .^{53}$

The Dublin Dockyard Company provides an example of the danger of conflating religion and political allegiance. Though the company was controlled by an exclusively Protestant board of British-born engineers, Smellie was among a group of Protestant Home Rulers within the business community, along with various members of the Quaker flourmilling family the Shackletons (though the proprietor of the Anna Liffey mill, George Shackleton, was a committee member of the Irish Unionist Alliance), the Unitarian proprietors of the largest brushmaking firm I.S. Varian \& Company, bacon curers Shaw of Limerick, and the proprietor of the largest southern jam and confectionery producer, Robert Woods. ${ }^{54}$ Families other than the Shackletons also showed signs of division within their ranks. Though the Kilkenny brewers, the Smithwicks, were a well-known nationalist family-one had been a leading Repealer with Daniel O'Connell, another a Home Rule MP-John Smithwick, principal of the firm, was a signatory to the 1893 Catholic petition against Home Rule, as indeed was O'Connell's younger son, owner of the Phoenix Brewery in Dublin. ${ }^{55}$

The railway companies and the banks accounted for the vast bulk of stock market capital at the time. ${ }^{56}$ Great Southern and Western Rail was the largest private-sector employer outside Ulster. Its 1913 workforce of around nine thousand was close to that of either of the massive Belfast shipyards, the largest industrial enterprises in the country. ${ }^{57}$ The rail transport sector had long been accused of anti-Catholic bias, though the Society for the Protection of Protestant Interests maintained that differences in educational attainment were the most likely explanation for the sectarian wage differentials that had been uncovered. ${ }^{58}$ The longterm chairman of the Great Southern was Sir William Goulding, who, along with the Arnotts, owners of a range of businesses including the Irish Times newspaper, would later be criticized by Presbyterian bookseller J. C. M. Eason for the reluctance they displayed in reconciling to

53. Irish Times, August 28, 1911.

54. Irish Times, January 25, 1913; Potter, Limerick's Merchants, 76.

55. Irish Times, March 24, 1893. The petition held that "the intended legislation would not only mean ruin to business and the general prosperity, but would damage the interests of their religion” (Irish Times, March 28, 1893). O'Connell's son stated that he was sure that if his father were alive, he would not consent "to hand over Ireland to the tender mercies of the so-called Nationalist leaders"; Irish Times, March $31,1893$.

56. Grossman et al., "Stock Exchange Index."

57. Bielenberg, "Irish Industry," reports that Harland and Wolffe, the larger of the two, employed almost 9,500 in 1907.

58. Society for the Protection of Protestant Interests, Reply, 6-8. 
the new political dispensation. ${ }^{59}$ The second-largest rail company was the Great Northern, whose lines ran from Dublin to Belfast and across the future Northern Ireland. It employed more than five thousand in 1913 and almost three thousand in the Free State alone in 1925. Its longterm chairman, Fane Vernon, was a member of the executive committee of the Irish Unionist Alliance. ${ }^{60}$ The Midland Great Western and the Dublin \& South Eastern were the other railway companies of significance. Both had also long been chaired by unionists. ${ }^{61}$ When Frank Brooke, chairman and managing director of the latter, was assassinated during the War of Independence he was followed as chairman (perhaps in anticipation of a change in the political dispensation) by Sir Thomas Esmonde, a Catholic and former Nationalist MP. ${ }^{62}$

There were nine banks operating in the Free State area. Of these, the Bank of Ireland, the Provincial, the Royal, and the three Belfastheadquartered institutions were unionist in ethos. The remaining three-the National, the Hibernian, and the Munster \& Leinster Bank —were viewed as broadly nationalist in outlook. ${ }^{63}$ Both the president and secretary of the Institute of Chartered Accountants were Protestant, as were most of the council and all of the partners of the dominant firms, Craig Gardner and Stokes Brothers \& Pim. ${ }^{64}$ Robert Stokes and Sir Robert Gardner were among the 150 southern business leaders to criticize the Home Rule Bill in 1913. ${ }^{65}$

Of the seven major Dublin department stores of the era, only Clery's was under Catholic nationalist control. ${ }^{66}$ Pim Brothers' drapery and furniture store, which had a workforce of six hundred in 1894, appears to have been the largest. ${ }^{67}$ Builders' providers remained strongly

59. Cullen, Eason \& Son, 390.

60. Both Goulding and Vernon were signatories to the Tory Business View criticism of the Home Rule Bill of 1913 (Irish Independent, November 27, 1913).

61. The MGW was chaired for almost forty years by Sir Ralph Cusack, upon whose death the position passed to his son-in-law (Irish Times, March 4, 1910).

62. The Irish Times reported that Brooke was "associated with matters which brought him into conflict with the forces of disorder in the country" (Irish Times, November 3, 1920); Irish Times, February 25, 1921. He was suspected of having passed information to the military authorities.

63. Campbell, Irish Establishment, 195. The Bank of Ireland had a complement of 550 officials in 1914; MacDonagh, "Victorian Bank," 41. The National had a more extensive branch network and employed around six hundred in Ireland in 1919: Irish Banking Magazine, 1920, cited in Oliver, "Business of Dublin.” The National Bank also had a number of branches in Britain.

64. Farmar, Versatile Profession, 65.

65. "Home Rule Finance: A Tory Business View," Irish Independent, November 27, 1913.

66. Barry, "Protestant Businesses."

67. Its nominal capital was bigger than both Arnott's and Clery's (Oliver, "Business of Dublin"). Arnott's employed only around two hundred at the time: Nesbitt, Arnott's, 37. 
Protestant dominated up to the $1960 \mathrm{~s} \cdot{ }^{68}$ By the end of the nineteenth century, Brooks Thomas and Dockrell's had emerged as the leading firms in the sector. ${ }^{69}$ Maurice Brooks, founder of the former and a member of the Church of Ireland, was succeeded as chairman at his death in 1905 by his son-in-law, Richard Gamble, a member of the City of Dublin Unionist Association. ${ }^{70}$ Sir Maurice Dockrell, Brooks's nephew, would serve as one of the few Unionist MPs elected for a Southern Irish constituency in 1918. Leading firms in cognate sectors included the Dublin timber firm T. \& C. Martin, whose proprietors were Catholic unionists. ${ }^{71}$ The principals of J. \& P. Good, one of the largest building contractors, and of Heitons and Tedcastle McCormick, the largest coal-distribution companies, were prominent unionists, as were the Findlaters, owners of a range of businesses including a chain of retail stores. ${ }^{72}$ The Findlaters, Tedcastles, Heitons, and Hewats (who took control of Heitons upon the founder's death) were expatriate Scottish Presbyterians.

The Alliance and Dublin Consumers Gas Company and the Dublin United Tramway Company were among the few large businesses not to conform to the general pattern unearthed. The gas company was a quasi-regulated monopoly provider of public lighting. Its origins as an 1866 amalgamation of existing gas companies left a legacy of political diversity on its board. It was chaired until 1914 by William F. Cotton, a Home Rule MP, who was succeeded in the role by John Murphy, a member of a leading Catholic unionist shipping family. ${ }^{73}$ The Gas Company employed at least 750 and perhaps substantially more in 1917. ${ }^{74}$ The Dublin United Tramway Company was part of the business empire of the leading Catholic nationalist industrialist of the day, William Martin Murphy. Murphy was also proprietor of the best-selling newspaper group, the Irish Independent, and part owner of Dublin department store Clery's. His

68. Quinn, “Industry Evolution,” 124.

69. Quinn, "Industry Evolution," 124. Firms in these segments do not appear to have exceeded the five hundred employee mark. Dockrell's was stated in 1912 to employ "several hundred workers and more than 60 clerical staff"; Whitaker's Red Book of Commerce.

70. MacMahon, Past Presidents, 92.

71. MacMahon, Past Presidents, 151-152; MacMahon: Meeting of Merchants, 139; "The Roman Catholic Petition,” Irish Times, March 24, 1893.

72. On the latter see Findlater, Findlaters.

73. Smith, Palgrave Murphy, 117. John Murphy's father, Michael, had attended the Dublin Unionist Convention of 1892 and been a signatory to the Catholic petition against Home Rule the following year.

74. Freemans Journal, November 7, 1917. 
various enterprises are likely to have employed a workforce of at least 1,500 in the late 1910 s. $^{75}$

Table 1 shows, in summary, that of the forty-five thousand workers in the firms listed, thirty-six thousand-some 80 percent of the total-were employed in Protestant unionist-controlled businesses. A Southern unionist, writing in 1912, suggested that few among the large employers "are in a position to help the Unionist cause effectively, for they have to deal with strike makers and possible boycotters."76 Even much smaller unionist employers made no effort to hide their political allegiances, however, while the first strike in the Guinness brewery's history was in 1974. ${ }^{77}$ Though Jacob's, the unionist-owned biscuit manufacturer, was centrally involved in the bitter industrial relations dispute of 1913, union leader James Larkin's main antagonist was Catholic nationalist industrialist William Martin Murphy. The unionist claim does not appear therefore to stand up to scrutiny. That all of the large firms would have had predominantly Catholic nationalist workforces may have shielded them from boycott: attacks on Goodbody properties ceased when the family warned that their operations might be closed down. ${ }^{78}$ Boycotts could be more effectively directed against retailers and distributors, and fear of antagonizing nationalist customers is understood to have conditioned the behavior of the retail banks. ${ }^{79}$ In the case of manufacturing, the boycott was a blunter instrument. It proved impossible, for example, to discriminate other than by geography in the 1920-1922 nationalist boycott of Belfast goods, and though the prime minister of the newly devolved Northern Ireland government believed that "a boycott of stout would be impossible," handbills advocating a counter-boycott urged the local population to "cease purchasing all southern goods," including stout, whiskey, and biscuits, which were produced almost exclusively by Southern unionist firms. ${ }^{80}$

Religion and politics aside, the data in Table 1 also tell us something of the degree of concentration in southern industry, though the analysis in this case is confined to manufacturing because of the availability of an appropriate denominator. ${ }^{81}$ The top twenty

75. The DUTC employed close to two thousand in 1929, by which time it operated bus as well as tram services (Weekly Irish Times, August 24, 1929). Its workforce numbered at least 750 in 1913 (Weekly Irish Times, August 30, 1913).

76. Rosenbaum, Against Home Rule, p. 186.

77. Flood, In Full Flood, 91.

78. Stewart, Goodbodys, 17-18.

79. Ollerenshaw, "Businessmen and Ulster Unionism," 38; Lyons, "Reflections."

80. Johnson, “Belfast Boycott,” 294-297.

81. The Free State-area manufacturing workforce in 1912 was around sixtynine thousand. The equivalent figure for Great Britain in 1907 was around 5 million (1907 Census of Production figures from Bielenberg, "Irish Industry,” table 1, p. 822). 
employers accounted for around twenty-four thousand jobs, or some 35 percent of the Free State-area manufacturing workforce, while the top twenty in Britain employed around three hundred thousand, some 6 percent of the equivalent workforce, and the top one hundred only around 13 percent. $^{82}$

\section{Unionist and Nationalist Views on the Union, Home Rule, and} Secession

Nationalists and unionists differed in their assessments of the economic consequences of the Union. Nationalists came to blame southern deindustrialization on the economic integration of the period, while the inadequate response to the Great Famine of the 1840s was ascribed to a distant and uncaring government. Though some unionists accepted that the arrangement may not have worked perfectly in the past, they pointed to the numerous benefits that the Union had delivered since 1890 as part of a policy that came to be known as "killing Home Rule with kindness." These included extensive land redistribution, democratic local government, improvements to education, and the establishment of bodies such as the Congested Districts Board and the Department of Agriculture and Technical Instruction. A generous old-age pension had also been introduced and subsidies granted to the post office, housing, and agriculture. ${ }^{83}$

Elements of self-interest were inextricably intertwined with differences in judgment as to the consequences of any change to the status quo. The Irish stock market, however, had fallen on occasion since the 1880s with news of progress on the passage through Westminster of one or another of the Home Rule Bills of the time. ${ }^{84}$ Hence there was an empirical basis to the 1913 warning by 150 "Tory business leaders" that Home Rule would raise the cost of finance and drive capital and industry from the country. ${ }^{85}$

The costs and benefits of prospective trade protection were a major point of divergence, as Edward Carson, the Dublin-born leader of northern unionism, made clear when he warned in 1921 that concerns over the potential industrial consequences of fiscal autonomy meant that

82. The precise number of jobs in the British case depends on whether military and admiralty facilities and the repair and construction yards of the railway companies-which are not included in the Free State-area list-are counted: Shaw, "Large Manufacturing Employers." The share of the top one hundred comes from Johnman, "Large Companies," 229.

83. Kennedy, Colonialism, 58-59. These arguments are presented in detail in the 1912 publication, Rosenbaum, Against Home Rule.

84. Hickson and Turner, "Irish Stock Market."

85. Irish Independent, November 27, 1913. 
Ulster "would not agree to it." ${ }^{86}$ As pointed out earlier, the Northern Ireland area was much more heavily industrialized than the South. It was also substantially more export oriented.$^{87}$ Similar fears had also been expressed by southern unionists, however, at a meeting chaired by Lord Ardilaun in 1911. ${ }^{88}$ The chairman of the convention established by the British in 1917 to try to secure agreement on an all-Ireland Home Rule solution noted that "the difficulties of the Irish Convention may be summed up in two words-Ulster and Customs." ${ }^{89}$ Britain conceded fiscal autonomy to the prospective new Irish Free State only toward the end of the Anglo-Irish Treaty negotiations of $1921 .^{90}$

Unionists differed from the majority of nationalists in their commitment to the imperial project. The 1917 proposal by Southern unionists that customs revenue be retained by Westminster as a contribution to war debt and defense would have achieved other of their aims as well, however, including ensuring continued representation in the imperial parliament. ${ }^{91}$ In an apparent conciliatory response to nationalists, they made the unorthodox suggestion that control of excise be separated from customs and delegated to any prospective new Irish parliament: by a happy coincidence this would have protected the Irish brewing and distilling industries from the temperance-oriented British parliamentarians of the era. ${ }^{92}$

Irish unionists were fearful of possible expropriation by a radical, vengeful, or sectarian Dublin parliament. ${ }^{93}$ They also feared the enactment of "hasty legislative proposals at the expense of the 350,000 loyalists who will be practically unrepresented but who pay most of the taxes."94 They professed themselves skeptical of nationalist

86. Memorandum by James O’Connor of an interview with Edward Carson, 1921, University College Dublin Archives, P150/1902. On the resistance of Ulster industry, see also Report of the Proceedings of the Irish Convention.

87. Northern Ireland and Free State exports amounted to $£ 64$ and $£ 51$ million, respectively, in 1924 (inclusive of transit trade), through the Free State economy was substantially larger; Ó Nualláin, “Comparison,” 532.

88. McDowell, Crisis \& Decline, 46. See also Buckland, Irish Unionism, 326.

89. Report of the Proceedings of the Irish Convention, 5.

90. Meenan, Irish Economy, 137.

91. "Memorandum by Southern Unionists on Fiscal Autonomy," Report of the Proceedings of the Irish Convention, appendix vii, 83.

92. Buckland, Irish Unionism, 109-118. Buckland reports that unionists at the Convention "talked over fiscal problems with the Guinnesses" (Irish Unionism, 99).

93. Rosenbaum, Against Home Rule, 184. The traditional Home Rule party heavily defeated by Sinn Féin in the 1918 general election spanned a broad spectrum of opinion on social issues (McConnell, "Imagining Home Rule”), though, as Rumpf and Hepburn, Nationalism and Socialism, note, "the more moderate the nationalism, the more conservative was its attitude towards the existing social system" (13).

94. Buckland, Irish Unionism, 266. The Guinness brewery alone was said to pay "something like four millions to the revenue"; Buckland, Irish Unionism, 218. 
competence on fiscal matters, as evidenced by Lord Midleton's complaint to Churchill in 1922 that

the people are exceedingly ignorant [and] morally cowards... Greatest extravagancies will probably be proposed and the proceedings [in the Free State parliament] show you how the government are likely to have their hands forced. ${ }^{95}$

That Ireland was overtaxed had long been an article of nationalist faith. Though supported by the findings of a British parliamentary committee of the 1890s, a follow-up report of 1912 found that the balance between expenditures and revenues had since been reversed. ${ }^{96}$ The old-age pension was the subject of particular comment. The recent UK Pensions Act had been designed with the industrial population of Great Britain in mind, though the same rates were payable in Ireland under the unified system of administration. The 1912 report regarded it as "absolutely certain" that an act designed by an Irish Parliament "would not have been of such a costly character as to absorb at one stroke nearly one-third of the total revenue of the country."97

Most on the nationalist side appear to have assumed that selfgovernment would rapidly bring prosperity. Tom Kettle, one-time Home Rule MP and first professor of national economics at University College Dublin, argued that much of the fiscal burden was the result of past misgovernment. ${ }^{98}$ Arthur Griffith, the founder of Sinn Féin, saw no reason why the island could not provide a living for a population of 15 million. ${ }^{99}$ Erskine Childers was almost alone among those on the nationalist side to recognize explicitly the financial difficulties that might have to be faced, particularly with respect to the adjustment to pensions that he felt would be required. ${ }^{100}$

Southern unionists also raised economic concerns over partition when it emerged as part of the policy agenda. A customs frontier between the two parts of Ireland would undoubtedly cause disruption. A report from Belfast to London immediately before the establishment of the customs frontier noted that "Dublin sends large consignments of Guinness's stout and porter, as well as spirits, mineral waters, tobacco, matches, biscuits, confectionary and provisions into Northern Ireland." ${ }^{101}$ The Southern linen supply chain was particularly

95. Buckland, Irish Unionism, 267.

96. Hynes, "Separation"; Irish Times, April 29, 1912.

97. Irish Times, April 20, 1912.

98. Kettle, Home Rule Finance, 33-35, cited in Ó Gráda, “The greatest blessing.”

99. Griffith, Resurrection, 166.

100. Childers, Home Rule.

101. Cited in Nash, Dennis and Graham, "Irish Border." 
vulnerable, as noted in a newspaper report from 1923 that pointed out that the linen trade in the South

is almost entirely dependent on the North for its supplies. Goods are also sent backwards and forwards across the border for dyeing, bleaching, etc., and if these movements are to be made more difficult and expensive it will certainly mean that an already hard-hit industry cannot be carried on. ${ }^{102}$

The Dublin Chamber of Commerce had warned that partition would exacerbate the lack of economic expertise by depriving the prospective southern parliament "of the steadying influence and business training of the men of Ulster." ${ }^{103}$ It also expressed concern at the costliness of the further duplication of administrative machinery that partition would entail. ${ }^{104}$

\section{Developments in Economic and Business Life Post- independence}

The first decade of independence proved much less traumatic for the former unionist business community than had been feared. One of the first acts of the Provisional Government was to appoint the Bank of Ireland as its financial agent in 1922. The new government prioritized stability, and the support of former unionists swung behind it when civil war broke out in 1922-23 over the terms of the Anglo-Irish Treaty. The informal partnership established between William Martin Murphy, Presbyterian Charles Eason, and Quaker George Jacob during the bitter Dublin lockout of 1913 helped to stabilize business sentiment. ${ }^{105}$ So too did the appointment by government of a number of former unionists, including Andrew Jameson, to the upper chamber of the new parliament, and the presence of brewer Richard Beamish, building contractor John Good, and coal distributor William Hewat among the four business representatives elected to the lower chamber in 1923.

Though it had been widely assumed that the Free State would be protectionist from the outset, only modest trade barriers were imposed in the first decade of independence, as had been predicted by William Martin Murphy, among others, in 1917. ${ }^{106}$ Export-oriented agriculture, in the view of the Free State Fiscal Inquiry Committee of 1923, "must be

102. Irish Times, March 3, 1923.

103. Irish Times, June 1, 1920.

104. Cullen, Princes, 93.

105. Cullen, Princes, 92.

106. Report of the Proceedings of the Irish Convention, 39, para. 21. 
considered as of paramount importance." ${ }^{107}$ Trade and banking interests had also been fearful that independence might lead to a severing of the currency link with sterling. By the time a decision on currency matters came to be made in 1927, hyperinflation had led to the collapse of a number of continental currencies and "hostility toward inflation [had become] the leitmotif of economic policy across Europe." 108 The one-to-one link with sterling was retained and would survive for a further fifty years. ${ }^{109}$

Unionist concerns that the new state might prove financially irresponsible were definitively laid to rest. The state was born into fiscal crisis. Compensation for property losses and expenditure on the army absorbed almost three-quarters of government revenue in $1924 .{ }^{110}$ The pension rate inherited from British rule would have had to have been cut by at least one-third were a relationship to national income equal to that in Britain to be established. A cut of one-tenth was imposed in preparation for the launch of the first national loan, when establishing the creditworthiness of the new state was a priority. ${ }^{111}$ The cut in the pension rate is widely understood to have been a factor in the government's defeat in the general election of $1932 .{ }^{112}$

As for the alternative of raising income tax, here too the government was constrained. It was believed that if economics lay at the core of the North-South divide, then low taxation might make a united Ireland more attractive to northern unionists. ${ }^{113}$ A further constraint was the danger of capital flight: "Some of those who paid large amounts in income tax were out of sympathy with the new regime and transferred their domicile to Great Britain." 114 By 1928 the Irish tax rate had been reduced below that of the United Kingdom and would remain lower under the more radical Fianna Fáil administrations that held office from $1932 .^{115}$

The business elite did not have everything its own way, of course, even in the 1920s. The auditing contracts for major new state

107. Fiscal Inquiry Committee, Final Report, (Dublin, 1923), para. 87.

108. Clavin, Great Depression.

109. FitzGerald and Kenny, "Debt," cite research showing that membership of the sterling bloc/Commonwealth area facilitated significantly lower borrowing costs in the troubled interwar period. Free State long-term bond yields started off around 1 percentage point higher than those for the United Kingdom, but the premium declined substantially over subsequent years; FitzGerald and Kenny, "Debt," table 8.

110. FitzGerald and Kenny, "Debt."

111. Ó Gráda, "The greatest blessing."

112. Farrell, Cumann na nGaedheal.

113. Regan, Counter Revolution, 254; Farrell, Cumann na nGaedheal, 103.

114. Meenan, Irish Economy, 246.

115. Meenan, Irish Economy, 246. For details of the standard rate of income tax in Ireland and the United Kingdom up to 1943, see Coleman and Considine, "No Income Tax Campaign," table 1. 
companies were largely directed to emerging Catholic firms rather than to the traditional accounting duopoly, and there were disagreements over railway amalgamation and electricity generation, with some developments pertaining to the latter criticized by business interests and the Irish Times as "socialist" and "confiscatory." "116 Significantly, the Free State did not follow the United Kingdom in abolishing the corporation profits tax in $1924 .{ }^{117}$ Objections to these measures were generally led by parliamentarians of the former unionist camp.

Though relations between the business establishment and the Fianna Fáil governments of the 1930s were more fraught, private sector attitudes toward protection had begun to change with the onset of the Great Depression, which preceded Fianna Fáil's accession to power. ${ }^{118}$ Goodbody Jute welcomed the protection it received from the encroachment of cheap imports from Calcutta, and expansion of the domestic sugar industry provided a new source of demand for its sacks and twines. The Southern linen industry, which had been threatened by the erection of a customs frontier with Northern Ireland, lobbied for the imposition of a tariff on imports. ${ }^{119}$ The department stores expanded their manufacturing businesses behind the tariff wall: Arnott's "thanked God and the government's economic nationalism of the 1930 s for the development of new knitting and making-up industries." ${ }^{20}$ The timber firms and builders' providers benefited from the expansion in housing construction initiated in Ireland (as in Britain) during the Depression. Guinness and Jacob's protected themselves by building or extending factories in England.

As to the impact of independence on economic growth, though relatively little convergence on UK living standards was achieved over the half-century to EEC membership Pollard suggests that Ireland's problems, rather than stemming from independence, "were more akin to those of the major non-industrialized regions inside advanced countries, like the Italian South, Corsica, and the French South-West."121

116. Barry, "Protestant Businesses." One of the main complexities in the formulation of railway policy was the significant role that the railways played in BritishIrish trade (Delaney, "Railways”). Unionists had earlier argued that Home Rule (and by extension secession) would impact adversely on the operation and development of transportation links between the two countries; Rosenbaum, "Against Home Rule,” p. 291, chap. 20.

117. de Cogan, "Corporation Tax."

118. O’Rourke, “Bigger Picture”; Daly, Industrial Development, 174.

119. Hall, "Partition”; Irish Times, December 7, 1931.

120. Nesbitt, Arnott's, 112.

121. Pollard, Peaceful Conquest, 324. O’Rourke, "Independent Ireland," shows Ireland (the Free State, and later the Republic) to have grown as rapidly as would have been expected on the basis of initial income over the period 1926-1938, and while it was substantially below the convergence line for 1950-1973, it nevertheless grew more rapidly than Scotland. 
Northern Ireland, which remained part of the United Kingdom, also underperformed. ${ }^{122}$

Many of the long-established firms, though they had become less export oriented over the protectionist era, remained on the list of the "fifty largest Irish industrial companies" published in 1966. ${ }^{123}$ The position at EEC accession in 1973 of each of the largest companies of the pre-independence era is detailed in Appendix 2. Though there were, of course, a diverse array of experiences, Goulding's remained by far the largest fertilizer company, the Odlum Group vied with RanksHovis (which had taken over Bannatyne in 1930) as the largest integrated bread and flour-milling operation, Guinness and Jacob's were respectively the largest and second-largest manufacturing establishments in Dublin, and the Guinness Group was the largest manufacturing employer in the country.

Sectarian divisions in the workplace had diminished by the 1960s but had not yet disappeared. ${ }^{124}$ Bowen reported that among a small survey group of south Dublin Protestants, most who had entered the labor market before 1955 had found their first positions in workplaces where the majority of their coworkers were Protestant. ${ }^{125}$ Developments external to the firms ensured that this could not persist indefinitely. As Lyons writes of the Bank of Ireland:

An increasingly Catholic representation on the Court of Directors and the recruitment of a predominantly Catholic staff would ... have become inevitable with the striking decline of the Protestant population in the decades after independence. ${ }^{126}$

Not all of the imbalances in recruitment and management were ascribable to sectarianism, as Cullen observes in his study of Eason's:

Staff were recruited from the immediate circle of the principal, and since many recruits were accepted on the recommendation of the

122. Crafts, "Golden Age."

123. These included Goulding’s, Hely's, Jacob’s, Goodbody’s, Brooks Thomas, Heiton, Greenmount \& Boyne, E. \& J. Burke, T. \& C. Martin, the Irish subsidiary of Ranks (which had bought out Bannatyne in 1930), and United Distillers (later Irish Distillers), into which Jameson and Power's had merged with Cork Distilleries (Irish Times, November 8, 1966). As the list only included companies traded on the Dublin Stock Exchange, Guinness, Denny, and a number of others do not appear.

124. Secretive organizations such as the Masonic Order and the Knights of Columbanus were thought to have been active in business life and to have promoted the recruitment and promotion of Protestants and Catholics, respectively.

125. Bowen, Privileged Minority, 95.

126. Lyons, "Reflections." 
senior people in the firm, continued recruitment tended to be slanted in that direction. ${ }^{127}$

Eason's first appointed a Catholic to its board in 1947. Craig Gardner appointed its first Catholic partner in 1944. Until the 1960s at least, however, many firms continued to be known to the public as either Protestant or Catholic. ${ }^{128}$ Businessman Michael Smurfit reports that Catholic firms such as his could find it difficult to make sales to Protestant companies, in many of which Catholics could never join the management team, "no matter how good they were at their job or how considerable the contribution that they could make."129

The liberalization of trade and ownership restrictions from the late 1950s triggered a wave of mergers and acquisitions that paid no heed to the religious associations of earlier times. ${ }^{130}$ The earliest developments took place in banking. To avoid the threat of foreign takeover, Bank of Ireland merged with the Hibernian Bank in 1958, a development that "would have astounded the Hibernian's founders [owing to] the political and religious preferences" of the former. ${ }^{131}$ The National Bank, another of the traditionally Catholic nationalist banks, joined the group in 1966. A similar fusion of traditions occurred with the formation of Allied Irish Banks later that year through the merger of the remaining southern banks. Stokes Brothers \& Pim merged with the Catholic firm Kennedy Crowley in 1972 to form the largest accountancy group in the state. The entrance of an American firm into the milk distribution business in 1964 triggered the merger of rival Catholic and Protestant distributors. Jacob's and Boland's Biscuits merged in 1966, as did Jameson, Power's, and Cork Distilleries. Smurfit acquired the previously merged Hely's and Alexander Thom in 1970. The old Protestant unionist firms Goulding's and Dockrell's were acquired by Catholic entrepreneur Tony O'Reilly in the early 1970s. Guinness bought up most of the remaining Irish brewers. ${ }^{132}$

127. Cullen, Eason \& Son, 111.

128. Farmar, Heitons, 34. The Irish Times noted in 1965 that "the day of the identifiably 'Protestant' or 'Catholic' firm is passing”; Irish Times, March 23, 1965.

129. Cited in Daly, Sixties Ireland, 126.

130. The mergers and acquisitions of the era are documented in Restrictive Practices Commission, Report. Scale was necessary for survival, and family firms were seen as particularly problematic; Garret FitzGerald, Irish Times, July 3, 1968; Committee on Industrial Progress, General Report, 37-38. The determination among some Protestant family firms to keep control in the hands of the shrinking body of co-religionists is argued to have become a particular source of weakness; Quinn, Industry Evolution, 137, 213.

131. Lyons, "Reflections," 209.

132. Barry, "Protestant Businesses." 
Liberalization too brought an increased focus on the importance of education, as represented by the publication of the landmark report Investment in Education in 1965. ${ }^{133}$ Education in Ireland up to that point has been described as designed to reproduce "a certain social type, pious, familial, loyal to the native acres, culturally ingrown and obedient to clerical guidance in matters moral and intellectual."134 This report by contrast, and others that followed in its wake, emphasized education as the means by which society invested in itself and prepared for the future. A major restructuring of the system was initiated and throughput expanded substantially. Educational credentials had formed a significant component of the criteria for public-sector recruitment since the foundation of the state: personal connections became relatively less significant from this time as a route through which new staff were recruited in the private sector. ${ }^{135}$

\section{Concluding Comments}

The paper has addressed questions as to the composition of the Southern Irish business establishment in the decades to the foundation of the Free State in 1922, the views of the business elite on the issues pertaining to Home Rule and secession, and the post-independence legacy of the divisions of the time between the business elite and the broader population. The substantial bulk of the significant firms are found to have been under Protestant unionist ownership and control. Though unionism largely overlapped with Protestantism, the business establishment also included small minorities of Protestant Home Rulers, Catholic unionists, and Catholic nationalists. Only in certain narrow segments did Catholic nationalists predominate.

Nationalists and unionists subscribed to different interpretations of the historical consequences of political and economic union within the United Kingdom. They also espoused different views as to the likely consequences of secession. Kennedy finds the debate between the two sides to have diminished in sophistication since the 1890s, as "the imminence of the realization of the nationalist dream made close analysis less of a necessity." 136 The fears of the unionist business community proved over the decades to have been largely unfounded. Only very modest tariffs were introduced in the 1920s because, earlier

133. Barry, "Irish Education System."

134. Garvin, Preventing the Future, 184.

135. Hence EEC membership, in the convergence analysis of O'Rourke, "Independent Ireland," serves as a proxy for a number of changes related to the liberalization process.

136. Kennedy, Colonialism, 59. 
nationalist rhetoric notwithstanding, this was the policy deemed by government to be in the national interest at the time. The shift to protectionism in the 1930s was part of a worldwide phenomenon. Many of the former unionist firms welcomed it in the context of the Great Depression, while the largest exporters avoided foreign trade barriers by engaging in tariff-jumping foreign direct investment. Macroeconomic discipline was maintained.

Paradoxically, while protectionism led to a large increase in the number of firms under Catholic nationalist ownership, it facilitated the survival of traditional business practices. The erosion of the sectarian divide in Irish business life accelerated dramatically with the opening up of the economy from the late 1950s. By the time of EEC entry, the era of tightly controlled family businesses was largely at an end, denominationally distinct workplaces had all but disappeared, many of the traditionally Protestant and Catholic firms had merged, and educational credentials were coming to displace personal connections as the main route through which new staff were recruited in the Irish business sector.

\section{Bibliography of Works Cited}

\section{Books}

Aldcroft, Derek H. Europe's Third World: The European Periphery in the Interwar Years. Aldershot, UK: Ashgate, 2006.

Bielenberg, Andy. Cork's Industrial Revolution 1780-1880. Cork: Cork University Press, 1991.

Bowen, Kurt. Protestants in a Catholic State: Ireland's Privileged Minority. Dublin: Gill and Macmillan, 1983.

Buckland, Patrick. Irish Unionism 1: The Anglo Irish and the New Ireland, 1885-1922. Dublin: Gill and Macmillan, 1972.

Campbell, Fergus. The Irish Establishment, 1879-1914. Oxford: Oxford University Press, 2009.

Childers, Erskine. The Framework of Home Rule. London: Edward Arnold, 1911.

Clavin, Patricia. The Great Depression in Europe, 1929-1939. New York: St. Martin's, 2000.

Cullen, Louis. Princes and Pirates: The Dublin Chamber of Commerce, 1783-1983, Dublin: Dublin Chamber of Commerce, 1983.

—. Eason \& Son: A History. Dublin: Eason, 1989.

Daly, Mary E. Social and Economic History of Ireland since 1800. Dublin: Educational Company, 1981.

—. Dublin: The Deposed Capital, 1860-1914. Cork: Cork University Press, 1984.

—. Industrial Development and Irish National Identity, 1922-1939. Syracuse, NY: Syracuse University Press, 1992. 
. Sixties Ireland: Reshaping the Economy, State and Society, 1957-1973, Cambridge: Cambridge University Press, 2016.

Dictionary of Irish Biography. Dublin: Royal Irish Academy; Cambridge: Cambridge University Press, 2009. https://dib.cambridge.org.

Farmar, Tony. Heitons-A Managed Transition: Heitons in the Irish Coal, Iron and Building Markets, 1818-1996. Dublin: A. \& A. Farmar 1996.

- The Versatile Profession: A History of Accountancy in Ireland since 1850. Dublin: Chartered Accountants Ireland, 2013.

Findlater, Alex. Findlaters: The Story of a Dublin Merchant Family 1774-2001. Dublin: A. \& A. Farmar, 2013.

Flood, Finbarr. In Full Flood: A Memoir. Dublin: Liberties Press, 2006.

Flora, P., F. Kraus, and W. Pfenning, State, Economy and Society in Western Europe 1815-1975. Vol. 2, Growth of Industrial Societies and Capitalist Economies. Chicago: St. James Press, 1987.

Garvin, T. Preventing the Future: Why Was Ireland So Poor for So Long? Dublin: Gill and Macmillan, 2004.

Griffith, Arthur. The Resurrection of Hungary. 3rd ed. Dublin: Whelan \& Son, 1918.

Henry Denny \& Sons Ltd., 1820-1970, A Brief History to Celebrate 150 Years of Private Enterprise. London: Denny Group, 1970.

Kennedy, Kieran, Thomas Giblin, and Deirdre McHugh. The Economic Development of Ireland in the Twentieth Century. London: Routledge, 1988.

Kennedy, Liam. Colonialism, Religion and Nationalism in Ireland. Belfast: Institute of Irish Studies, 1996.

Kettle, T. Home Rule Finance: An Experiment in Justice. Dublin: Maunsel \& Co., 1911.

MacMahon, Enda. Brief Biographies of the Past Presidents of Dublin Chamber Of Commerce 1783-2011. Dublin: Dublin Chamber of Commerce, 2012.

- A Most Respectable Meeting of Merchants, Dublin Chamber of Commerce: A History. Dublin: Londubh, 2014.

McDowell, R. B. Crisis \& Decline: The Fate of the Southern Unionists. Dublin: Lilliput Books, 1997.

Meenan, James. The Irish Economy since 1922. Liverpool: Liverpool University Press, 1970.

Nesbitt, Ronald. At Arnott's of Dublin, 1843-1993. Dublin: A. \& A. Farmar, 1993.

Ó Gráda, Cormac. Ireland: A New Economic History 1780-1939. Oxford: Clarendon Press, 1994.

Pollard, S. Peaceful Conquest: The Industrialization of Europe, 1760-1970. Oxford: Oxford University Press, 1981.

Potter, Matthew. Limerick's Merchants: Traders and Shakers. Limerick: Limerick Chamber, 2015.

Regan, John. The Irish Counter Revolution, 1921-1936: Treatyite Politics and Settlement in Independent Ireland. Dublin: Gill and Macmillan, 2001.

Riordan, E. J. Modern Irish Trade and Industry. New York: E. P. Dutton, 1920.

Rosenbaum, S., ed. Against Home Rule: The Case for the Union. London: F. Warne, 1912. 
Rumpf, E., and A. C. Hepburn. Nationalism and Socialism in TwentiethCentury Ireland. Liverpool: Liverpool University Press, 1977.

Slater, Sharon. A Stitch in Time: A History of Limerick Clothing Factory. Limerick: Limerick Archives, 2017.

Smith, Cornelius F. The Shipping Murphys: The Palgrave Murphy Shipping Line 1850-1926. Dublin: Albany Press, 2004.

Stewart, M. Goodbodys of Clara, 1865-1965. London: Neame, 1965.

Strattens' Dublin, Cork and South of Ireland: A Literary, Commercial and Social Review. London: Stratten and Stratten, 1892.

Townsend, Brian. The Lost Distilleries of Ireland. Castle Douglas, UK: Neil Wilson, 2012.

Whitaker's Red Book of Commerce, or Who's Who in Business. London: J. Whitaker and Sons, 1912.

Articles, Chapters in Books, Dissertations, Papers, and Reports

Barry, Frank. "Outward-Oriented Economic Development and the Irish Education System.” Irish Educational Studies, 33, no. 2 (2014): 213-223.

—_ "The Leading Manufacturing Firms in the Irish Free State in 1929." Irish Historical Studies, 42, no. 162 (2018): 293-316.

—. "The Life and Death of Protestant Businesses in Independent Ireland." In Protestant and Irish: The Minority's Search for Place in Independent Ireland, edited by Ian d'Alton and Ida Milne, 155-170. Cork: Cork University Press, 2019.

Bielenberg, Andy. "What Happened to Irish Industry after the British Industrial Revolution? Some Evidence from the First U.K. Census of Production in 1907." Economic History Review, 61, no. 4 (2008): 820-841.

—. "The Industrial Elite in Ireland from the Industrial Revolution to the First World War." In Politics, Society and the Middle Class in Modern Ireland, edited by Fintan Lane, 148-175, Basingstoke: Palgrave Macmillan, 2010.

Black, Sandra E., and Elizabeth Brainerd. "Importing Equality? The Effects of Globalization on Gender Discrimination." Industrial and Labor Relations Review, 57 (2004): 540-559.

Board of Trade Journal. London, 1928.

Brownlow, G. "The Causes and Consequences of Rent-seeking in Northern Ireland,1945-72." Economic History Review, 60, no. 1 (2007): 70-96.

Chen, Z., Y. Ge, H. Lai, and C. Wan, "Globalization and Gender Wage Inequality in China." World Development, 44 (2013): 256-266.

Coleman, Kieran, and John Considine. "The No Income Tax Campaign: TwentyFirst Century Tax Philosophy in 1920s Ireland." Irish Economic and Social History, 33 (2006): 1-17.

Committee on Industrial Progress. General Report. Dublin, 1973.

Cork: Its Trade \& Commerce, Official Handbook of the Cork Incorporated Chamber of Commerce \& Shipping, 1919.

Crafts, N. F. R. "The Golden Age of Economic Growth in Postwar Europe: Why Did Northern Ireland Miss Out?" Irish Economic and Social History, 22 (1995): 5-25. 
de Bromhead, A., A. Fernihough, and E. Hargaden. "Representation of the People: Franchise Extension and the 'Sinn Féin Election' in Ireland, 1918." Journal of Economic History, 80, no. 3 (2020): 886-925.

de Cogan, D. "The Wartime Origins of the Irish Corporation Tax." Irish Journal of Legal Studies, 3/2 (2013): 15-32.

Delaney, D. "Irish and English Railways, 2." Journal of the Irish Railway Record Society, 17, no. 110 (1989): 106-119.

Farrell, Mel. “'Few Supporters and No Organisation’? Cumann na nGaedheal Organisation and Policy, 1923-33." PhD thesis, Department of History, National University of Ireland, Maynooth, 2011.

Fiscal Inquiry Committee. Final Report. Dublin, 1923.

FitzGerald, John, and Séan Kenny. “'Till debt do us part': Financial Implications of the Divorce of the Irish Free State from the UK, 1922-6." European Review of Economic History, 24, no. 4 (2020): 818-842.

Frieden, J., and L. Martin. "International Political Economy: Global and Domestic Interactions.” In Political Science: The State of the Discipline, edited by Ira Katznelson and Helen Milner, 118-146. New York: Norton, 2003.

Gibney, Desmond, and Martin Quinn. "Management in the Early Days of the Irish Free State: Bennetts of Ballinacurra." Irish Journal of Management, 37, no. 1 (2019): 35-50.

Grimes, Thomas. "Starting Ireland on the Road to Industry: Henry Ford in Cork." PhD thesis (in two volumes), Department of History, National University of Ireland, Maynooth, 2008.

Grossman, Richard., Ronan Lyons, Kevin O’Rourke, and Madalina Ursa. “A Monthly Stock Exchange Index for Ireland, 1864-1930.” European Review of Economic History, 18 (2014): 248-276.

"Guinness Archive Fact Sheet, Numbers Employed by Arthur Guinness Son \& Co. Ltd." Dublin: Archive Department, Guinness Storehouse.

Hall, Donal. "Partition and County Louth." Journal of the County Louth Archaeological and Historical Society, 27, no. 2 (2010): 243-282.

Hickson, C., and J. Turner. "The Rise and Decline of the Irish Stock Market, 1865-1913." European Review of Economic History, 9, no. 1 (2005): 3-33.

Hynes, William. "To What Extent Were Economic Factors Important in the Separation of the South of Ireland from the United Kingdom and What Was the Economic Impact?" Cambridge Journal of Economics, 38, no. 2 (2014): 369-367.

Irish Unionist Alliance. 30th Annual Report, 1919-1920. Dublin, 1920.

Johnman, L. "The Large Manufacturing Companies of 1935." Business History, 28, no. 2 (1986): 226-245.

Johnson, D. S. “The Belfast Boycott, 1920-1922.” In Irish Population, Economy and Society, Essays in Honour of the Late K.H. Connell, edited by J. M. Goldstrom and L. A. Clarkson, 287- 307. Oxford: Clarendon Press, 1981.

Kennedy, Liam. "Nationalism and Unionism in Ireland.” In Unhappy the Land: The Most Oppressed People Ever, the Irish?, 53-77. Dublin: Irish Academic Press, 2016.

Levine, R., A. Levkov, and Y. Rubinstein, "Bank Deregulation and Racial Inequality in America." Critical Finance Review, 3, no. 1 (2013): 1-48. 
Lyons, F. S. L. "Reflections on a Bicentenary.” In Bank of Ireland 1783-1983, Bicentenary Essays, edited by F. S. L. Lyons, 197-217. Dublin: Gill and Macmillan, 1983.

MacDonagh, Oliver. "The Victorian Bank, 1824-1914.” In Bank of Ireland 1783-1983, Bicentenary Essays, edited by F. S. L. Lyons, 31-53. Dublin: Gill and Macmillan, 1983.

McConnell, James. "Imagining Home Rule." In The Irish Parliamentary Party and the Third Home Rule Crisis, chap. 10. Dublin: Four Courts Press, 2013.

Meenan, James. "Irish Industry and Industrial Policy, 1921-1943." Studies: An Irish Quarterly Review, 32, no. 126 (1943): 209-218.

Montalvo, J. G., and M. Reynal-Querol. "Religious Polarization and Economic Development.” Economics Letters, 80 (2003): 201-210.

Nash, Catherine, Lorraine Dennis, and Brian Graham. "Putting the Border in Place: Customs Regulation in the Making of the Irish Border, 1921-1945." Journal of Historical Geography, 36 (2010): 421-431.

O'Gorman, Colm, and Declan Curran. "Strategic Transformations in Large Irishowned Businesses.” Business History, 59, no. 4 (2017): 497-524.

Ó Gráda, Cormac. “'The greatest blessing of all’: The Old Age Pension in Ireland." Past \& Present, 175, no. 1 (2002): 124-161.

Oliver, Emmit. "The Business of Dublin in the Early 20th Century: An Overview of the Retail and Financial Sectors." Dublin Historical Record, 71 (2019): 236-250.

Ollerenshaw, Philip. "Businessmen and the Development of Ulster Unionism, 1886-1921." Journal of Imperial and Commonwealth History, 28, no. 1 (2000): 35-64.

O'Malley, Eoin. "The Decline of Irish Industry in the Nineteenth Century." Economic and Social Review, 13, no. 1 (1981): 21-42.

Ó Nualláin, Labhras. "A Comparison of the Economic Position and Trend in Éire and Northern Ireland." Journal of the Statistical and Social Inquiry Society of Ireland, 17 (1946/47): 504-540.

O'Rourke, K. "Independent Ireland in Comparative Perspective." Irish Economic and Social History, 44, no. 1 (2017): 19-45.

O'Rourke, Kevin. "Ireland and the Bigger Picture.” In Refiguring Ireland: Essays in Honour of L.M. Cullen, edited by D. Dickson and C. Ó Gráda, 342-355. Dublin: Lilliput Press, 2003.

Payne, P. L. "The Emergence of the Large-Scale Company in Great Britain, 1870-1914." Economic History Review, 2nd series, 20 (1967): 519-542.

Quinn, James. "Industry Evolution: A Comparative Study of Irish Wholesaling." $\mathrm{PhD}$ thesis, School of Business, Dublin City University, 2002.

Railway Companies: Staff and Wages. London, 1913.

Report of the Proceedings of the Irish Convention. Dublin, 1918.

Restrictive Practices Commission. Report of Studies into Industrial Concentration and Mergers in Ireland. Dublin, 1976.

Returns of Railway Companies. Dublin, 1926.

Saorstát Éireann. Census of Industrial Production 1926 and 1929. Dublin, 1933.

Shaw, Christine. "The Large Manufacturing Employers of 1907." Business History, 25, no. 1 (1983): 42-60. 
Society for the Protection of Protestant Interests. Reply to the Catholic Association and Its Allies, "The Leader" and "The Irish Rosary." Dublin: Society for the Protection of Protestant Interests, 1903.

Unionist Convention Dublin (Provinces of Leinster, Munster and Connaught). Report of Proceedings. Dublin, 1892.

Ulster Year Book 1926. Belfast, 1926.

Newspaper and Magazines

Cork Examiner (Cork)

Freemans Journal (Dublin)

Irish Banking Magazine (Dublin)

Irish Independent (Dublin)

Irish Times (Dublin)

Weekly Irish Times (Dublin)

Archives

University College Dublin Archives 


\section{Appendix 1 Selected Sources on Unionist Affiliations}

Source Business leaders ${ }^{\mathrm{a}}$

Great Unionist Demonstration, Dublin, 1887

Unionist Convention for the Provinces of Leinster, Munster and Connaught, Dublin 1892

Others listed as unionist in the 1890s

Catholic petition against Home Rule, 1893

Irish Unionist Alliance, 1913

South Co. Dublin Unionist Registration Association, 1915

Irish Unionist Alliance, 1919-1920

Unionist Anti-Partition League, 1919
Lord Ardilaun, James Talbot Power, John Jameson, Sir John Arnott, T. P. Cairnes, Maurice Dockrell, Robert Tedcastle, Pim (various), Goodbody (various) ${ }^{1}$

J. F. G. Bannatyne, Pim (various), T. P. Cairnes, Maurice E. Dockrell, Sir Richard Martin, Lord Ardilaun, Sir John Arnott, Goodbody (various), W. J. Goulding, Lord Iveagh, John Jameson, Whyte family of Balbriggan (various), Beamish (various), George Pollexfen, Sir John Power, F. H. Thompson, T. H. Cleeve, Sir Ralph Cusack ${ }^{2}$

Sir Henry Cochrane, ${ }^{3}$ Frank Brooke, ${ }^{4}$ Michael Murphy, ${ }^{5}$ James Ogilvie, 6

Charles and Richard Martin, James and John Talbot Power, John Smithwick, Michael Murphy ${ }^{7}$

Sir John Arnott, Cairnes (various), Sir Maurice Dockrell, Sir Robert Gardner, Sir William Goulding, Goodbody (various), Guinness (various), William Hewat, G. N. Jacob, Jameson (various), F. V. Martin, J. Mooney, Sir John Nutting, Pim (various), J. F. Stokes, Fane Vernon ${ }^{8}$

Viscount Iveagh, Sir Maurice Dockrell, Sir Stanley Cochrane, Andrew Jameson, Frank V. Martin, Sir John Nutting, James Talbot Power ${ }^{9}$

Sir John Arnott, Guinness (various), Odlum (various), W. P. Cairnes, C. E. Denny, George Shackleton ${ }^{10}$

Sir John Arnott, John Good, Sir William Goulding, Guinness (various), Viscount Iveagh, Andrew Jameson, John Mooney, Sir Harold Nutting ${ }^{11}$

\footnotetext{
${ }^{a}$ In the vast majority of cases, the businesspersons named were delegates or officials rather than ordinary members of the various associations.

${ }^{1}$ Irish Times, December 3, 1887.

${ }^{2}$ Unionist Convention Dublin, Report of Proceedings.

${ }^{3}$ Irish Times, June 18, 1892.

${ }^{4}$ Irish Times, April 18, 1896.

${ }^{5}$ MacMahon, A Most Respectable Meeting of Merchants, 139.

${ }^{6}$ Freemans Journal, November 29, 1897.

${ }^{7}$ Irish Times, March 15 and 24, 1893.

${ }^{8}$ Irish Independent, November 17, 1913.

${ }^{9}$ Irish Independent, June 4, 1915.

${ }^{10}$ Irish Unionist Alliance, 30th Annual Report, 1919-1920.

${ }^{11}$ Irish Times, January 28, 1919.
} 


\section{Appendix 2 History to EEC accession (1973) of the largest firms of the pre-independence era}

\author{
Firm \\ Guinness (brewing) \\ W. \& R. Jacob (biscuits) \\ Condensed Milk Co. of Ireland \\ (dairy produce) \\ J. \& L. F. Goodbody (sacks) \\ Kynoch's (explosives) \\ Denny (bacon) \\ Boland's (bread and flour) \\ Johnston, Mooney \& O’Brien \\ (bread and flour) \\ Goulding's (fertilizer)
}

Dwyer \& Co. (clothing, footwear, and furnishings)

Bannatyne (flour)

Blarney Woollen Mills (woolen textiles)

Limerick Clothing Factory (clothing)

Cork Spinning \& Weaving (linen)

Greenmount Spinning \& Weaving (linen)

Boyne Weaving (linen)

Hely (Paper products and printing) Alexander Thom (Paper products and printing)

Ford (motor vehicles)

Dublin Dockyard Co. (shipbuilding)

Great Southern \& Western Railway Co. (railways)

Midland Great Western (railways)

Dublin \& South Eastern (railways)
Position ca. 1972-73

Guinness brewery remains Dublin's largest manufacturing establishment with a workforce $\approx 3,500$. Guinness Group is Ireland's largest manufacturing employer with a workforce $\approx 5,000$ and accounts for $>90$ percent of the Irish stout, ale, and lager market.

Remains Dublin's second-largest manufacturing establishment with a workforce $\approx 2,500$.

Collapsed in early 1920 s.

Had transitioned by 1973 from jute to polypropylene. Employs $\approx 1,000$.

Closed ca. 1918.

Long surpassed as Ireland's main bacon curer and no longer an Irish company, workforce $\approx 400$.

Remains one of Dublin's major bakeries, workforce $\approx 750$.

Remains one of Dublin's major bakeries, workforce $\approx 500$. Acquired by Odlum Group in 1972, which brings the Odlum workforce to ca. 1,200.

Largely ceased exporting in the early 1920 s. Continued to hold 50 percent of the Irish market in the early 1970 s, with workforce $\approx 1,400$. Merges into Fitzwilton in 1972.

Workforce $\approx 400$, though a number of other much larger firms have been established by family members.

Acquired by UK firm Ranks in 1930, from when Ranks (later Ranks-Hovis) expand further in Ireland.

Workforce remains $\approx 510$.

Acquired by a UK company in 1969 , by which time employment has declined to 270 .

Closed in late 1920s.

Amalgamated to form Greenmount \& Boyne in early 1920s, with 800 employed in 1960. By early 1970 s, linen is no longer produced, Greenmount factory has closed, and employment has declined to ca. 200.

Amalgamated to form Hely-Thom in 1962. Acquired by Smurfit in 1970, at which time its workforce $\approx 750$.

Workforce $\approx 1,500$.

Closed early 1920 s.

Amalgamated in 1924/1925 to form Great Southern Railway Co. Merged with Dublin United Transport Company in 1944 to form what would become the state transport company CIE. 
(Continued)

Firm

Position ca. 1972-73

Great Northern Railway Co. (railways)

Bank of ireland (banking)

National Bank (banking)

Pim Bros. (retail)

Eason \& Son (wholesale and retail side of printing business)

Alliance and Dublin Consumers Gas Co. (town gas)

Dublin United Tramway Co. (trams and buses)
Nationalized in 1950s with assets divided between Ulster Transport Authority (Northern Ireland) and state transport company CIE.

Bank of Ireland Group formed by merger with Hibernian Bank in 1958. National Bank merges into Bank of Ireland Group in 1966. By 1973, the group is one of a duopoly in Irish banking alongside Allied Irish Banks.

Acquired by a UK consortium in mid-1950s. Closes 1967.

Remains one of the major firms in its area of business. Workforce $\approx 950$.

Remains a privately owned monopoly provider of piped gas for the Dublin region. Workforce $\approx 1,400$.

Merged in 1944 into what becomes the state transport company CIE. 